\title{
Gender, numbers and substance: women parliamentarians and the 'politics of presence' in KwaZulu-Natal
}

\author{
Suzanne Francis
}

\begin{abstract}
This article investigates four dimensions of the political institutional representation of women by women parliamentarians in KwaZulu-Natal. It begins by exploring whether or not women Members of the Provincial Parliament (MPPs) actively seek to substantively represent women, and how they do this. Secondly, it probes the perceptions they hold of their impact in this area. Third, the question of whether and how contested conceptions of political representation impact on attempts to feminise the agenda, is raised. Lastly, the article explores the impact of women MPPs via the institutional mechanism of the Women's Parliamentary Caucus (WPC). The results show that the majority of parliamentary women do seek to represent women and claim effectiveness in doing so. Challenges to this agenda however include party identity, and racial and cultural conceptions of representation that divide women and strengthen resistance to change. It was also found that while the WPC provides an arena for women to elucidate their specific concerns and partly circumvent the constraints of party and racial and cultural representation, its institutional inadequacies were found to impact negatively upon the women's agenda - a factor recognised only by a minority of women MPPs.
\end{abstract}

\section{Introduction}

Traditionally, accounts of women in parliament have been concerned with the achievement of formal political equality with men. At the heart of such studies is the concept of the 'politics of presence' (Phillips 1995) which posits that legislatures should reflect the social composition of the population. This is deemed to be essential to the authenticity of the entire system of democratic representation. In this view, the concept of a representative democracy demands the inclusion of social groups that have been excluded 
due to structural discrimination, and implies that representation should be proportionate. In these terms, gender parity in the numerical composition of parliamentary representation is a question of justice and citizenship (Hassim 1999). It is simply not just for men to dominate political representation and for women to be excluded from the formal arenas in which their rights as political citizens are exercised.

Studies that investigate the numerical increase of women in parliaments have explored supply and demand factors in legislative recruitment (Childs 2000, Norris and Lovenduski 1995). Some posit that the potential numerical representation of women in politics is greatest in countries that employ a party-list proportional representation system in a multi-party parliamentary democracy (Haavio-Mannila et al 1985, Krook 2004, Lovenduski 1986, Norris 1987, Phillips 1991, Rule 1981). Such parties may use their lists to promote numerical gender equality through a quota system, ensuring the political inclusion of women so as to secure the authenticity of representative democracy.

A dimension implicit in the 'politics of presence' (Phillips 1995) is the idea that the representivity of women will make both a symbolic and a substantive difference. That is, by their very presence in the legislature, women will ensure that dominant groups cannot ignore their interests and their perspectives will be articulated (Phillips 1999). Within this domain, women will bring a different set of values and concerns to politics that challenge the dominance of powerful interest groups.

Feminist political theorists have focused upon the impact of women parliamentarians on decision-making and the consideration of women's concernsı in policy. In a study of citizenship, for example, Hassim argues that "citizenship has to be understood in both formal as well as substantial terms... and social policy demands and interventions by feminists should be aimed at establishing a more egalitarian context for women citizens' (Hassim 1999:16). Critical mass studies consider the 'when and how' of the potential impact of numerical representation on political practice (Bystydzienski 1992, Grey 2002, Krook 2004, Lovenduski 2001, Norris 1996). For example, some authors conclude that it is when women constitute 15 per cent of representatives that they begin to have an impact on policy such that women will benefit (Bystydzienski 1992, Grey 2002, Phillips 1991).

However this is contested terrain. A critical mass of women in public office may not make a substantial difference without 'women [being] conscious of and [articulating] their particular needs and abilities' (Bystydzienski 
1992:15). A critical mass may only begin to make a difference when women engage in 'critical acts' (Lovenduski 2001:757); collectively effecting changes to benefit women. While a quota system may create a critical mass of women, it is not certain that these same women will consider themselves responsible for engaging in critical acts for the benefit of women per se, nor is it certain that women who comprise diverse interest groups will act in unison. This is the point of entry into the debate of the argument made here. A key aspect of the 'politics of presence' is surely what representatives actually do. The question is, do women in parliament perceive that their presence also includes a second dimension of representation, that of acting to benefit women in society through policy changes? And if women do seek to actively make a difference for women through their legislative roles, one needs to ask what prevents them from actually doing so.

Studies of women in African politics depict a long history of women's activism for women and have focused upon the roles of women in political protest (Hassim 2006, Walker 1991) and women's engagement with the state, through women's or liberation movements (Hassim 2006, Goetz and Hassim 2003). In the context of colonialism, the process of 'divide and rule' manipulated racial, ethnic and gender identities, ensuring differentiated societal roles and 'distinct forms of engagement' with the state (Pankhurst 2002:119). This is exemplified in apartheid South Africa by the employment of race solidarity to protect class interests, dividing women (Walker 1990:343).

With the entrenchment of democratic political institutions in South Africa post-1994, theorists have investigated whether or not the state has provided an effective framework for gender transformation. Both Hassim (1998) and Goetz (1998) found this to be the case. Although in the South African parliament numbers alone are insufficient to advance women's concerns (MacGregor 1999), women parliamentarians in South Africa have been the primary agents in ensuring an engendered agenda (Ross 2002). On the other hand, scholars have also examined the ways in which national liberation movements in power subsumed women's concerns to other struggles (Connell 1998:196-9) and provided a reason for limited action. African feminists debate the role of African cultural norms in the shaping of indigenous feminisms (Hasse 1991). In her discussion of the commitment of the African National Congress (ANC) to engendered policy, Walker (1994) found gender equality and tradition in South Africa to be fundamentally incompatible. Indeed barriers to the agency of women may be 'backed by ... tradition and custom' (Geisler 1995:547). 
This study takes on the second aspect of the 'politics of presence' in order to ask whether or not the representivity of women makes a difference. This is achieved through an exploration of four dimensions of substantive political institutional representation of women by parliamentary women in the context of the Provincial Parliament of KwaZulu-Natal.2 It is first considered whether parliamentary women in KwaZulu-Natal perceive that they substantively represent women, and how they conceptualise and go about this work. The article then examines whether they believe that their presence in parliament effectively advances women's concerns. Third, parliamentary women's views of how other conceptions of political representation impact on their ability to transform the agenda, are explored. Lastly an attempt is made to evaluate the extent of women parliamentarians' impact through their perception of the capacity of the Women's Parliamentary Caucus (WPC), a political institutional forum intended to advance women's concerns.

\section{Methodology and context of the study}

This study employed semi-structured interviews with 76 per cent $(n=16)$ of women parliamentarians in the KwaZulu-Natal Provincial Legislature. The non-response rate, which was not party specific, constituted 24 per cent $(n=5)$. Anonymity was a condition of the interviews, thus quotations remain unreferenced to interviewees. 3

At the time of writing, women constitute 26 per cent of elected representatives in the KwaZulu-Natal provincial parliament, in contrast to 29.8 per cent in the South African national parliament. The provincial parliament enjoys a legislative mandate in exclusive areas of provincial policy and shares powers with the national legislature to enact legislation and implement policy in a range of other areas. The National Council of Provinces may also contribute to national legislation and scrutiny through a permanent delegation to parliament.

At a global level, South Africa ranks eleventh in terms of the numerical representation of women in parliament, making the country something of an anomaly in the developing world. Legislation enacted since 1994 has prescribed formal equality with regard to the rights of men and women, and established institutions designed to protect those rights. Prior to this, African women were subject to customary norms that treated them as minors. Inherited from the past is a patriarchal society with deeply entrenched perceptions across racial groups that decision-making is a 'male' domain, with the social contract reserved for men. South Africa's history, which 
included the migrant labour system, segregation, apartheid, 50 years of Bantu authorities and acute racial and labour divisions, forms the backdrop to the fracture lines visible across South African society today.

In KwaZulu-Natal, the history of party political contest has added a unique dimension to women's experience. Emerging from a low intensity ten-year civil war between the Inkatha Freedom Party (IFP) and the African National Congress (ANC) (see Bonnin 2006, Jeffrey 1997), the discourse of politics in this province has centred on maintaining peace in forums consisting mostly of men. For political parties, the goal has been to increase the share of the popular vote in a context of acute competition.

In the second democratic election, in 1999, the IFP and the ANC formed a coalition government at a provincial level. This was overturned by an agreement between the IFP and Democratic Alliance (DA) in 2002, and again by a narrow ANC election victory in 2004. In 2009, the ANC increased its majority in a hotly contested election with the IFP. Although the ANC is the only party that employs a formal quota system, in that every third position on the parliamentary list was allocated to a woman before 2009, and gender parity in the list placings was ensured in the 2009 elections, women have substantial numerical representation in most parliamentary parties with the exception of a handful of minority parties (constituting five per cent of representatives).

\section{Parliamentary women's perceptions of how they represent women}

Over 70 per cent of parliamentary women interviewed perceived a gendered dimension to their political representation, and more than 50 per cent indicated that they acted for women. These interpretations were conceived of alongside more traditional constituencies such as 'the people', 'my party' or 'the province', and micro-groups such as 'the formerly disadvantaged'. Over 40 per cent of the women interviewed claimed to have prioritised women's concerns prior to becoming parliamentarians, and said that their placing on the parliamentary list was a direct result of gender-specific work they had done in the women's movement or within the women's sections of their parties. While prior experience in representing women does not guarantee that such women will continue to act for women, the majority of those citing such experiences said they intended to extend that work while in parliament.

Two women MPPs stated explicitly that they did not attempt to act for women. While recognising the unequal position of women in relation to men in KwaZulu-Natal, one interviewee contended, '... women have a raw deal...but ... I see myself as representing people, not any specific group ... 
Women [must] stop whining, stop saying we're not empowered, stop saying we are discriminated against!' This perception indicates both the difficulties in unpacking the complex and broad layers of justice, and also demonstrates how women's concerns can become subsumed within other struggles.

However, the majority of parliamentary women in KwaZulu-Natal do conceptualise their constituencies as including women and a substantial proportion seek to act on women's behalf or claim women as a target group for representation. How did these women MPPs understand women's concerns?

\section{Defining women's concerns}

In defining women's concerns, women MPPs initially spoke of 'development issues' or 'women's rights' as policy areas of most importance, broadening the definition from traditional concerns to include public-policy issues. Interviewees were asked to unpack their initial assertions in more detail. Their listing of concerns is given in Table 1.

As shown in Table 1, a variety of concerns was articulated. Individually, interviewees tended to group their concerns into confined clusters, which could be indicative of a difficulty in defining a shared conceptualisation or set of concerns. For example, one group of women discussed concerns perceived traditionally as lying within the female domain, such as childcare, maintenance payments, abortion and domestic violence, without mentioning developmental concerns. Another group incorporated rights-based approaches. As one woman concluded, 'I am here to ensure that women are treated as human-beings, equal to others in all ways'. However in both cases there is clear recognition of a direct correlation between MPPs' actions as representatives on behalf of women, and women's formal political equality with men.

A further group considered progress in the development and implementation of public works programmes to benefit women as a basis for the representation of women, but this group was divided in their perceptions of what constituted development for women. Some argued that as women were most affected by underdevelopment, all development was critical. As one stated,

Women suffer the most from lack of water, electricity and transport. They have to walk to collect wood to make fire, walk to fetch water from the river or... standpipe ... When... children get sick it is the women who must carry them to hospital. 
Table 1: On which concerns are you most interested in acting for women?

\begin{tabular}{|l|c|}
\hline Women's Concerns & Number of responses \\
\hline Domestic violence, rape, abuse & 10 \\
\hline Rural development, rural poverty, land reform & 8 \\
\hline HIV/AIDS, antiretroviral drugs for pregnant women & 6 \\
\hline Abuse of children & 4 \\
\hline Education, literacy & 4 \\
\hline Customary law & 4 \\
\hline Healthcare & 3 \\
\hline Self-help empowerment schemes & 3 \\
\hline Criminal justice & 3 \\
\hline Gender equality & 3 \\
\hline Informal sector employment & 2 \\
\hline Maintenance, childcare & 2 \\
\hline Housing & 2 \\
\hline Transport & 2 \\
\hline Water & 1 \\
\hline Electricity & 1 \\
\hline Domestic workers rights & 1 \\
\hline Sex workers rights & 1 \\
\hline Abortion & 1 \\
\hline
\end{tabular}

Note: Multiple responses allowed.

While directly challenging the 'male $=$ political sphere', 'female $=$ private sphere' dichotomy, other parliamentary women disputed that development for all would be sufficient to empower women. As one said, 'even where we have installed a standpipe, the women must wait until the youth have washed their cars before they can wash the clothes'. This illustrates the difficulties of untangling reinforced societal gender constructions that display acute developmental needs. Moreover, in a society with deeply entrenched patriarchal assumptions that place women at the bottom of the hierarchy in terms of access to resources, 'development for all' may do little to benefit women in a situation where resources are limited and communities employ patriarchal notions in the sharing of them. Thus, while women may indeed 
benefit from 'more development', gender-neutral conceptualisations of representation obscure the salience of women's concerns in regard to existing male-female power relationships in communities with acute developmental needs (as well as those communities with substantial resources).

As the second group of women representatives argued, the substantive representation of women should also be conceptualised as taking into account the manner in which male-female power relationships in society are affected by the way women's concerns are incorporated into policy. As one woman MPP stated, 'We are trying to prioritise women ... in policies that come before us'. Another, in discussing the prioritisation of women in agriculture, said:

Women work hard on the land but ... don't own it. When their husbands left ... they had nothing. Now we want to change all these things so that women can own land ... can be empowered.

For these women, substantive political representation means intervening directly to change the nature of the male-female power relationship within society.

\section{Taking action}

One way in which parliamentary women conceived of their duties as political representatives, was taking action on behalf of women in their parliamentary duties. This included raising women's concerns as parliamentary motions or as questions to ministers, and scrutinising policy in portfolio committees. Five interviewees recounted attempts to influence policy implementation. Just two of the women differentiated between having a general influence across parliamentary debates, and specifically targeting arenas where the agenda is set. In moving from general attempts to react to policy and attempting to have an influence across parliament, these women are demonstrating their recognition that real influence requires the targeting of specific areas in which policy is initiated.

Parliamentary women in KwaZulu-Natal have attempted in four main ways to provide channels for interest articulation on the part of nonparliamentary women in the province. Several interviewees gave examples of how they had been approached by women with problems that they would then take up on their behalf in parliament. As one MPP recalled:

I have just had a phone call from a woman. She is looking after babies of relatives who have died from AIDS... I don't think that the men in 
this parliament are actually aware of the burden that women carry in this

country.

Another MPP reflected that 'I've had a lot of women phoning with different problems. I ... see things from a woman's point of view'.

In both cases, these MPPs acknowledged a shared affinity with women constituents for whom they sought to make substantive changes. In doing so, they expressed a perception of gender difference among male and female parliamentarians. Moreover, both examples illustrate that women MPPs perceive that women construct the world and act in a fundamentally different manner to men. In acting for women, female MPPs are combining traditional notions of representation (acting on behalf of constituents) with more feminised ones (prioritising women's concerns in parliament).

Parliamentary women have also acted as the bridge between the parliamentary agenda and women's organisations in non-parliamentary party sections, and in NGOs working for the benefit of women. More than 40 per cent of interviewees cited examples in which they had taken up concerns in parliamentary committees originating in the IFP Women's Brigade or ANC Women's League. These women also acknowledged responsibility to the women's sections that had, in some cases, nominated them for office or supported their nominations.

Non-governmental organisations that seek to act for women have been actively encouraged by parliamentary women to access parliament through them, in order to lobby government indirectly. As one MPP explained:

We made contact with civil society organisations in order to forward questions to MECs ... We then forward the questions ... under our women's names ... and through this we make MECs more accountable on women's issues.

This input has reinforced the support networks of women MPPs, enabling them to remain engaged with women's concerns.

At the same time, acting as a channel for interest articulation enables parliamentary women to operate from a safe space, free of disapproval from their male colleagues. While actively working behind the scenes to facilitate questions on women's concerns, ensuring that such concerns reach and remain on the agenda, female parliamentarians can simultaneously refrain from ownership of them, remaining unlabelled as being concerned with women's issues only.

Some interviewees understood their being in power as in itself acting for 
women, in the sense that they were 'a role model' for other women. This form of representation was conceptualised as 'doing nothing specific' to assist women beyond challenging traditional roles. Whether this offers a sufficient basis for the substantive representation of women may be questioned. However, these women have defined their contribution as providing encouragement to women bound in the private sphere by normative assumptions about women's roles and challenging attitudes among their male parliamentary colleagues. In this context, this may be interpreted as a substantive contribution.

A related argument was the view, expressed by some women MPPs, that in order to actively represent women they had to be directly involved in community work. Role models are perceived to need to 'get involved with the community'. One interviewee discussed her representation in such terms, saying: 'I formed this sewing skills group to empower women ... I help

... one day each week'. It seems that this MPP has elided the action of representing women in order to bring about change, with the action of bringing about change through participation in the activity itself. Rather than using the available institutional framework in order to bring about change, it seems that she has focused upon another arena of change by collapsing the distinction between representation and participation. In this particular context, the struggle history of engagement with the state through civic action meant that political elites became representatives, in many cases, because of prior community participation. In this way, women MPPs may consider that their role of representation includes participation.

Following extensive discussion of the women's concerns on which they were most eager to have an impact, two women described their representation in terms of the gender-specific roles they had occupied prior to becoming parliamentarians. One regarded her commitment to women's concerns more than ten years earlier as synonymous with acting on behalf of women in the present, noting: 'I was a delegate at ... Codesa [Conference for a Democratic South Africa]. I led the delegation with specific reference to women's needs'. An integral part of such conceptualisations is the confusion between occupying a position of power as a woman (numerical representation) and representing women's concerns while a representative (substantive representation). Little evidence was provided of the way in which substantive political representation continued once access to state power was granted.

For two further women, the actual form of representation was largely confined to the discussion of matters relating to women MPPs and the 
development of support networks to assist parliamentary women. Seemingly, these women MPPs have equated political representation with support of one another in the parliamentary setting, rather than the support of one another to enable more effective representation of women.

While conceptualisations of substantive political representation are multiple, most women MPPs in KwaZulu-Natal demonstrate that their political representation includes a gender dimension, and that they have sought to act for women. Yet whether they substantively represent women through the political institutional spaces of which they are a part, does for some remain contested.

\section{Women parliamentarians' perceptions of their effectiveness}

The overwhelming majority of parliamentary women in KwaZulu-Natal argue that their presence in parliament favourably influences women's concerns. Examples they raise include: successes in legislating on matters of concern to women, organising campaigns to raise awareness of women's concerns, and intervening in policy in order to prioritise women or to make policy more women friendly.

Twenty percent of interviewees contended that, in their absence, men parliamentarians would not seek to substantively represent women. One MPP asserted, 'These men ... tell you that they believe in equality ... yet they think women should really know their place ... I don't see one instance of a man raising a matter to do with women'. This implies that distinctive gender-based experiences underlie the desire to engender the agenda and that men and women articulate those experiences differently.

On the other hand, more than half the women MPPs interviewed felt that their impact in parliament was limited by what may be interpreted as intrinsic factors related to the diverse groupings of women inherent in a parliamentary setting. Three women claimed a lack of capability among women MPPs as a reason why they did not achieve more in their political careers. One woman, discussing herself, contended, 'It seems as if I have to go and learn from someone'. Another suggested that some women MPPs did not possess the necessary expertise to adequately intervene on behalf of women:

Most of the women don't have the capacity. We attended a Gender and Budget Workshop recently. Many women ... have no idea what the budget is. Technocrats come and tell us, but how do you know it is working when you have no capacity to monitor anything.

This is suggestive of a tension between the main tenets of representative 
democracy and present-day parliamentary responsibilities. While some women possessed legal skills, the majority possessed no public accounts or other financial expertise. This was particularly the case with women from rural and peri-urban communities whose prior role had been confined by customary norms and who were limited by an insufficient familiarity with gender policy development. This suggests that effectiveness requires more than a conscious articulation of women's concerns and a sense of shared identity with women.

Whether or not women MPPs were actually having an influence was a contested issue. Three parliamentary women indicated that they considered the achievements claimed by other parliamentary women to be misplaced. As one argued, 'some women don't seem to understand that you can add as many references to women as you like [into legislation] ... but unless it changes their lives, it means nothing'. Another echoed these sentiments. For these women, impact was related to the change experienced by women rather than the effort employed to effect change. This suggests multifarious definitions of impact or effectiveness, no doubt informed by different histories and discourses.

Multifarious interpretations of effectiveness also stretched to a variety of interpretations of action. While more than 50 per cent of women conceptualised acting for women as a process of performing an activity, it appeared that four women perceived action as absorbing information which might facilitate more action for women. One example is indicative.

We act for women ... and we really make a difference ...we are often brought information from the National Women's Caucus and the Commonwealth Parliamentary Association ... the technocrats come and tell us about the budget every year.

This example illustrates a conflation of the distinction between actively informing policy and being informed of policy and it suggests variance in interpretations of participation.

Women MPPs also perceived that their impact was limited because they have not thus far occupied key institutional decision-making positions. Assertions made in this regard include the comment that, "we only get the opportunity to monitor the content after it has been decided'. This reflects a perceived correlation between their effectiveness and their access to the upper echelons of power. It also suggests that women were forced to be reactive rather than proactive because a glass ceiling restricted their ability to mainstream women's concerns within policy-making. 
A related point was the belief that, without the support of powerful male patrons, women's impact in parliament was limited. When pressed, women related improvements in their ability to further a women's agenda, and to their success in securing the support of the male Speaker in parliament. Conversely, given that they had not attempted to recruit ordinary male MPPs, this suggests that women MPPs perceive that an institutional position of influence held by a sympathetic man is more useful to furthering a women's agenda than male support itself.

While these were the challenges parliamentary women identified and perceived as being integral to why more had not been achieved, it is argued here that the most critical challenges lie in contested conceptions of political representation.

\section{The impact of contested conceptions of political representation}

Party identity as a conception of political representation was revealed in this study as one of the main reasons why women MPPs had failed to define a shared agenda and strategy to advance women's concerns. That is, party identity emerged as a key challenge to agenda transformation.

One result of the centrality of party identity as a conception of political representation was inter-party rivalries that limited the impact of efforts to engender the agenda by isolating clusters of women and contributing to their disengagement from collective action on women's issues. More than 40 per cent of the interviewees admitted that, 'there are partisan problems', 'infighting' and women often 'put their party first'. Competition between political parties clearly reduces support for women's concerns. For example, some of the concerns listed in Table 1 received little cross-party support from the women interviewed. Although they were concerned to see assistance provided to HIV-infected pregnant women, only recently did ANC women parliamentarians openly support the IFP's initiative to provide anti-retroviral drugs to such women. Likewise, although concerned about women's status, IFP women avoided debates about the role of customary law in perpetuating inequalities.

Moreover, such competition between political parties meant that women were unlikely to support each other in legislative debates to benefit women. As one said:

... the last speech I gave was about the Women's Parliamentary Caucus.

There were a bunch of women behind me chatting and heckling ... They

didn't listen to a word I said, never mind support it'. 
Constrained by the salience of party affiliation, many women were found to be concerned to advance women's concerns only so long as the recognition was won for their own political party. Three women indicated that while they might agree with a policy preference to benefit women, they would not guarantee that they would support it if it were initiated by, and associated with, a political party other than their own. A different MPP, from a minority party, discussed an initiative in which she had designed a policy to counteract child abuse and had had to pretend that [one of the larger parties] had initiated it or it would never have got off the ground'. In political contexts with acute party competition, attempts to engender the political agenda are likely to be subsumed by the parties' overwhelming aspiration for an increase in their popular support; the role of MPPs, including women, is subsumed in political point scoring against one another.

Women MPPs, although concerned to assert that their particular party supported women's concerns, articulated a hierarchy of political issues within their parties in which women's concerns feature only minimally. One MPP indicated that while she felt able to organise around women's concerns in the legislature, 'gender issues are not discussed in the party'. Another provided an account of how her scheduled Women's Day speech for the party was scrapped and '[A male colleague] presented a speech on party politics instead ...'

The root of this particular hierarchical prioritisation of political issues within parties appears to be twofold. First, the party is an arena that tends to replicate contested societal rankings of social groups. As one MPP stated, 'traditional leaders come first, then... men, then... women'. As another explained, 'we are taught to respect men. Women form the majority of our membership... we elect men into leadership positions'. Constrained by the party's ranking of them as a social group, women were found to be unlikely to raise concerns on matters that adversely affect women so long as a member of another social group better placed in the party hierarchy was an advocate of such concerns. One woman MPP clearly referred to this tension in an example she provided. She said, 'the question of polygamy contradicts the party and its membership but you won't get the women here to raise it. That would mean contradicting our leadership'.

While substantive political representation of women may be hindered by many factors, the party is the agent that reconstructs and reproduces the structures of patriarchal society in government. In such an instance, the party-list system and the critical mass thesis appear in tension with one 
another. Although a party-list system of proportional representation might increase the number of women in parliament, women MPPs are reliant upon the party for their list placing and thus are much less willing than they would be in a constituency based system to challenge party directives and informal hierarchies that are unsupportive of an engendered agenda. The advancement of women's concerns, in this context, appears to be in tension with a sustainable political career.

A second factor that has influenced the particular hierarchy of issues within parties in KwaZulu-Natal is racial and cultural conceptions of political representation that divide women in terms of racially and culturally defined boundaries. When articulating their concerns (Table 1), women were found to be divided along racial and cultural lines. White English-speaking women emphasised first-generation rights such as constraining customary law, workers' rights and rights over the physical body - rights designed to alter the position of women in relation to the law. In contrast, more black isiZulu-speaking women emphasised second-generation rights such as healthcare, education and rural development. These concerns focused less on the position of women in relation to men and more on ensuring that developmental goals incorporate women. Such stark divisions in priorities are the product of women's differing racial and cultural experiences. The poorest group in KZN remains rural black women who have limited access to the provisions of the modern state, and for whom improvement in firstgeneration rights means little without social and economic improvement.

These divisions circumscribe the ability of women MPPs to conceptualise concerns in unison and to articulate a shared position. More than 20 per cent of women MPPs provided examples which indicate that women's concerns in parliamentary parties remain overshadowed by a preoccupation with shared affinity with one's racial or cultural group. As one said:

[A male MPP]... said to the [Gender] Commission that there is no such thing as gender abuse in rural areas. The commission ruled that there was, so he called the commission 'racist'... Half the women in our party supported him.

In this instance, a racial discourse of shared interests was found to cut across that of gender, and loyalty to a community constructed racially proved the most salient feature of identification. Women MPPs were found to be unwilling to criticise practices that may be seen as oppressive to women when they are associated with their own cultural or racial group, and women's concerns were found to be inscribed disparately among women 
associated with different racial and cultural groups. Cultural peer pressure resulted in acquiescence and in some cases saw women MPPs acting against other women. As one woman MPP stated:

I have faced ... criticism from other women in my own culture ... One colleague... said to me, 'If you want to be irresponsible and take issue with [the institution of] traditional leadership then that is absolutely your own business, but first take a look at who you are siding with ...what will it be next? Africans can't govern?'

Embodied within this statement is a perception that advancing women's concerns in one arena might impact negatively upon the preservation of a collective cultural identity; a perception that criticism of a particular practice might be seen as an attack upon the value systems embodied in that culture. Indeed, in a society where power was formerly defined by race, the continuing salience of the desire to protect the ties that united oppressed groups is hardly surprising. However, such racial and cultural conceptions of political representation in KwaZulu-Natal divide women by diffusing their ability to impact upon the agenda and strengthening the interest groups resisting agenda transformation.

\section{The WPC as an institutional mechanism for agenda transformation}

Established in 1997 as a unit within the provincial legislature of KwaZulu-Natal, the Women's Parliamentary Causus (WPC) provides an inter-party forum for women MPPs. More than 60 per cent of women MPPs said that the WPC was an important arena for women. The WPC can be seen as an arena through which the identities of parliamentary women as women are reinforced and their subconscious assimilation into the legislature is minimised.

Four women thought that the WPC was an arena through which they were validated as women. Three more indicated that the WPC was the only arena in parliament in which women constituents were considered independently. In drawing gendered boundaries around the group, the WPC removes women from the patriarchal assumptions of their male colleagues, if temporarily, and reminds women MPPs of their affinity as women.

The WPC can further be seen as an arena in which women parliamentarians are both intellectually unrestrained in enunciating women's concerns, and sheltered from the informal disciplining effects of the legislature. Two women recognised that because the minutes of the WPC meetings did not individualise contributions, women could speak without recrimination. Five further women indicated that they considered the WPC to be an arena in which they were protected because 'the men in this house' could not 
observe them as individuals. Another explained that as members of the WPC they had mandated one woman to report back to the legislature as spokeswoman. In this way women could act with one voice and bridge some salient divisions among them. A form of solidarity among women in the WPC was thus conveyed to the legislature that may result in more critical acts.

Significantly, the WPC is an arena in which the boundaries of party and cultural identification may potentially be circumvented. More than 30 per cent of interviewees who were found to be negative about the impact of party and cultural identification on a woman's agenda, thought the WPC to be an arena where such divisions were less pronounced. In fact, some of the strategies employed by women MPPs to shield themselves as individuals had worked to break down party allegiances and enable collective action. As one woman noted, apparently to her own surprise, 'to be honest, we can be sat there and I often forget that we are from different parties...'

The most important outcome of the establishment of the WPC has been the protection it has afforded to women MPPs and consequently the potential it has provided for them to become feminised so that they may, in the future, perform more critical acts.

\section{Functions of the Women's Parliamentary Caucus}

The functions of the WPC as conceptualised by women MPPs were diverse and, in some cases, dissimilar. Although officially the functions of the WPC as tabled in the legislature are to "monitor ... implementation, ... [to share] information on gender issues in ... legislation and lobbying, ... to link with other women's organisations ... [and] to monitor ... empowerment programmes' (RSA 1997:619-1), none of the interviewees fully articulated these functions. Table 2 illustrates the functions of the WPC as expressed by parliamentary women in the sample.

Table 2. What are the functions of the Women's Parliamentary Caucus?

\begin{tabular}{|l|c|}
\hline \multicolumn{1}{|c|}{ Functions of the WPC } & Number of Responses \\
\hline Gatekeeping, monitoring and scrutinising & 5 \\
\hline Highlighting issues, sensitising, improving awareness & 5 \\
\hline Support group, empowerment group & 3 \\
\hline Celebrating women & 3 \\
\hline Uncertain & 3 \\
\hline
\end{tabular}

Note: Multiple responses allowed. 
The table reveals a failure to recognise a common set of purposes for the WPC. Five women contended that the WPC served a gate-keeping and monitoring role in parliament. These responses included statement such as, 'we check that delivery is happening with reference to women'. Five women indicated that they thought the function of the WPC was to highlight awareness of women's concerns rather than to oversee parliamentary performance on behalf of women. Three women suggested that the WPC was an arena in which women MPPs could improve parliamentary skills. Three women suggested that the purpose of the WPC was to celebrate and validate women. Other women admitted to uncertainty.

While the absence of a common agenda for the WPC appears on the surface as a failure to familiarise themselves with the mandate of the committee, the root of this failure is found in institutional inadequacies that have forced women to redefine their mandate in order to do what they can do, rather than what they should do.

\section{Institutional inadequacies of the Women's Parliamentary Caucus}

One way of examining the impact of women MPPs is to consider their conceptualisations of the institutional position and power to act that they possess through the WPC. More than 40 per cent of women pointed to institutional inadequacies that severely curtailed the impact of the WPC. Of these, six claimed that the root of their limitations lay in the structural relationship of the WPC to the legislature. As a result of the institutional position of the WPC, these women made the link that, "we cannot take decisions so... [we] are not dealing with anything effectively'. They have recognised that the institutional status of the WPC was a key factor in empowering women MPPs to effectively impact on the agenda.

The remainder of the women interviewed did not link institutional status with impact. While two women realised that the influence of the WPC was confined in comparison to other institutional structures in the legislature, they did not consider why this was so. One stated, 'it does absolutely nothing ... it is the worst committee'. This MPP collapsed the institutional distinction between committees and caucuses, omitting to recognise that the potential for action might be limited by the framework in which action occurs.

A failure to understand the impact of institutional status on their ability to transform the agenda led many parliamentary women to conclude that the problem lay mainly with the WPC itself. Eight women considered a lack of 
resources as the primary impediment to furthering a women's agenda. Of these, six pointed to drawbacks resulting from the WPC having no budget, one viewed secretarial assistance as the main limitation and another pointed to a lack of mechanisms for public involvement. These MPPs neglected to consider that results might be transformed by the WPC being afforded an improved institutional status.

A substantially negative result of the fact that the majority of parliamentary women failed to link institutional status with outcomes, was that the level of commitment to the WPC appeared to be deteriorating. Women parliamentarians complained that 'attendance is very poor' and 'meetings are cancelled when something else comes up'. Rather than examining the institutional reasons why more had not been achieved, women tended to retreat. Hence the one institutional space that offers the potential for women to set aside their party affiliations and racial and cultural conceptions of representation was under threat. Only when parliamentary women recognise the importance of the institutional status of the WPC will more be done for women.

\section{Conclusion}

The majority of parliamentary women in KwaZulu-Natal acknowledge women's concerns as a dimension of their political representation, and perceive distinctive gender-based experiences as underlying their ability to act for women. This correlates with the idea that 'women's common experience of subordination under patriarchy creates common political interests among women' (Hassim 1999:13). However, despite a belief that their presence is effective, multifarious conceptualisations of what it means to be so were evident. Whilst clusters of women have defined women's concerns distinctly and act decisively on the basis of those distinctions, some have not and they do not act in unison. Although the Women's Parliamentary Caucus offers the potential for women to operate from a 'safe space' in furthering a women's agenda, this will not be realised unless women recognise the impact of the WPC's current institutional inadequacies and seek to improve its status in parliament. Perhaps, in part, this is a consequence of an underdeveloped institutional capacity. While South African women have a long history of successful protest and lobbying externally to the parliamentary environment, their experiences of constructing and then utilising formal political institutional spaces to their benefit has been relatively short in comparison. 
Another critical challenge to an engendered agenda is women's racial and cultural conceptions of political representation, which manifest as both intraparty and inter-party divisions, effectively fracturing lobbying on women's concerns. The diverse histories and discourses through which women have come to construct women's concerns and their own representative role is perhaps the underlying reason why some of the boundaries presented to women have not been circumvented through collective action.

In this context, the critical mass thesis may be challenged. The party-list system of proportional representation might indeed increase the proportion of women representatives - satisfying the first dimension of the politics of presence, that of formal political justice. However, in the KwaZulu-Natal context of acute party competition, where the salience of racial and cultural conceptions of political representation divides women, women in parliament without constituency support are unlikely to challenge the party directives of a predominantly male leadership that reproduces and maintains the structures of a patriarchal society. Bridging these distinct identities is the biggest challenge to a concerted strategy of acting for women, and herein lies the crux of the problem.

Substantive justice and citizenship demand that women in parliament act effectively for women in society. The replication of diverse interest groups of women into parliament offers an authentic voice to their formal political representation, but it is not a voice that speaks in unison. The party list system in which quotas are employed increases the number of women in parliament, but that same system holds them hostage to patriarchal assumptions about their role and divides them further from one another. In further dividing women, party competition in parliament becomes a vehicle for the reassertion of patriarchy and its replication within parties. In this context of acute party competition, the very system that fulfils the first dimension of the 'politics of presence' also hinders its second dimension the effective use of that presence - to the detriment of women in society.

\section{Notes}

1. The term 'women's concerns' is employed throughout this paper to refer to matters that affect or touch upon, have reference or relation to, or engage the attention of women without surmising the preferences of women on such matters or whether or not women acknowledge that they might have any specific interest in them. For ways in which this term has been employed elsewhere see Childs (2001) and Cockburn (1996). 
2. The meaning of the term 'substantive political representation' in this paper is twofold. First, it refers to the actions of parliamentary women in re-presenting women's concerns as they might apply to, or be defined by, non-parliamentary women. Such concerns are often gathered through the method of public participation and concern the individual voices and experiences of women. Secondly, it refers to the ways in which women parliamentary representatives come to define the greater interests of those they represent in accordance with a higher purpose to make collective changes for the benefit of women. For heuristic reasons, both frameworks have been employed simultaneously.

3. The majority of interviews for this study were conducted during January-April 2007, September-November 2007 and January-April 2008, while the third Provincial Legislature of KwaZulu-Natal was in session. During this period the Women's Parliamentary Caucus met infrequently.

\section{References}

Bystydzienski, JM (1992) 'Influence of women's culture on public politics in Norway', in JM Bystydienski (ed) Women Transforming Politics: worldwide strategies for empowerment. Bloomington and Indiana: Indiana University Press.

Bonnin, D (2006) 'Legacies of political violence: an examination of political conflict in Mpumalanga Township, KwaZulu-Natal, South Africa', Transformation 62.

Childs, S (2000) 'The new Labour women MPs in the 1997 British parliament: issues of recruitment and representation', Women's History Review 9(1).

(2001) 'In their own words: new Labour and the substantive representation of women', British Journal of Politics and International Relations 3(2).

(2002) 'Hitting the target: are Labour women MPs acting for women?', Parliamentary Affairs 55.

Cockburn, C (1996) 'Strategies for gender democracy', European Journal of Women's Studies 3.

Connell, D (1998) 'Strategies for change: women and politics in Eritrea and South Africa', Review of African Political Economy 76.

Geisler, G (1995) 'Troubled sisterhood: women and politics in Southern Africa: Case studies from Zambia, Zimbabwe and Botswana', African Affairs 94.

Goetz, A (1998) 'Women in politics and gender equity in policy: South Africa and Uganda', Review of African Political Economy 25(76).

Goetz, A and S Hassim (2003) No Shortcuts to Power: African women in politics and policy-making. London: Zed Books.

Grey, S (2002) 'Does size matter? Critical mass and New Zealand's women MPs', Parliamentary Affairs 55. 
Haavio-Mannila, E, D Dahlerup and M Eduards (1985) Unfinished Democracy: women in Nordic politics. New York: Pergamon.

Hasse, R (1991) 'Gender, social location and feminist politics in South Africa', Transformation 15.

Hassim, S (1998) 'Les relations homes-femmes dans les institutions en Afrique du Sud: une nouvelle forme de politique', L'Afrique Politique.

(1999) 'From presence to power: women's citizenship in a new democracy', Agenda 40

(2006) Women's Organisations and Democracy in South Africa: contesting authority. Pietermaritzburg: University of KwaZulu-Natal Press.

Jeffrey, A (1997) The Natal Story: 16 years of conflict. Johannesburg: South African Institute of Race Relations

Krook, ML (2004) 'Reforming representation: the diffusion of candidate gender quotas worldwide', in K Ross (ed) Women, Politics and Change. New York: Oxford University Press.

Lovenduski, J (1986) Women and European Politics: contemporary feminism and public policy. Brighton: Wheatsheaf.

(2001) 'Women and politics: minority representation or critical mass', Parliamentary Affairs 54.

MacGregor, K (1999) 'The politics of empowerment: women in parliament', Indicator South Africa 16(3).

Norris, P (1987) Politics and Sexual Equality: the comparative position of women in western democracies. Boulder Colorado: Lynne Reiner.

(1996) 'Women politicians: transforming Westminster?', Parliamentary Affairs 49.

Norris, P and J Lovenduski (1995) Political Recruitment. Cambridge: Cambridge University Press.

Pankhurst, D (2002) 'Women and politics in Africa: the case of Uganda', Parliamentary Affairs 55.

Phillips, A (1991) Engendering Democracy. Cambridge: Polity Press.

(1995) The Politics of Presence. Oxford University Press: Oxford.

(1999) 'Democracy and the representation of difference.' Lecture presented to Aalborg University, September 16 and then published by the Research Programme on Gender Empowerment and Politics, Aalborg University.

Republic of South Africa (RSA) (1997) KwaZulu Natal Provincial Legislature: debates and proceedings 2 . 
Ross, K (2002) 'Women's place in male space: gender and effect in parliamentary contexts', Parliamentary Affairs 55.

Rule, W (1981) 'Why women don't run: the critical contextual factors in women's legislative recruitment', Western Political Quarterly 34(1).

Walker, C (1990) 'The woman's suffrage movement: the politics of gender, race and class', in C Walker (ed) Women and Gender in Southern Africa to 1945. David Philip: Cape Town.

(1991) Women and Resistance in South Africa. Cape Town: David Philip.

(1994) 'Women, tradition and reconstruction', Review of African Political Economy 21(61). 